\title{
Green and Cost-Effective Synthesis of Metallic Nanoparticles by Algae: Safe Methods for Translational Medicine
}

\author{
Bushra Uzair $1,+\left(\mathbb{C}\right.$, Ayesha Liaqat ${ }^{1,+}{ }^{+}$, Haroon Iqbal $^{2}$, Bouzid Menaa $^{3}$, Anam Razzaq $^{2}$, \\ Gobika Thiripuranathar ${ }^{4} \mathbb{D}$, Nosheen Fatima Rana ${ }^{5}$ and Farid Menaa ${ }^{3, *},+\mathbb{D}$ \\ 1 Department of Bioinformatics and Biotechnology, Islamic International University, \\ Islamabad 44000, Pakistan; bushra.uzair@iiu.edu.pk (B.U.); ayesha.bsbio23@iiu.edu.pk (A.L.) \\ 2 College of Pharmaceutical Sciences, Soochow University, Suzhou 215123, China; \\ harooniqbal415@hotmail.com (H.I.); anamrazzaq.ajk@gmail.com (A.R.) \\ 3 Department of Oncology and Nanomedicine, California Innovations Corp., San Diego, \\ La Jolla, CA 92037, USA; bouzid.menaa@gmail.com \\ 4 Institute of Chemistry Ceylon, College of Chemical Sciences, Welikada, Rajagiriya 10107, Sri Lanka; \\ tgobika@ichemc.edu.lk \\ 5 Department of Biomedical Engineering \& Sciences, School of Mechanical \& Manufacturing Engineering, \\ National University of Sciences \& Technology, Islamabad 44000, Pakistan; \\ nosheen.fatima@smme.nust.edu.pk \\ * Correspondence: dr.fmenaa@gmail.com \\ + Equal contribution.
}

Received: 7 September 2020; Accepted: 17 September 2020; Published: 16 October 2020

check for updates

\begin{abstract}
Metal nanoparticles (NPs) have received much attention for potential applications in medicine (mainly in oncology, radiology and infectiology), due to their intriguing chemical, electronical, catalytical, and optical properties such as surface plasmon resonance (SPR) effect. They also offer ease in controlled synthesis and surface modification (e.g., tailored properties conferred by capping/protecting agents including $\mathrm{N}_{-}, \mathrm{P}_{-}, \mathrm{COOH}-, \mathrm{SH}-$ containing molecules and polymers such as thiol, disulfide, ammonium, amine, and multidentate carboxylate), which allows (i) tuning their size and shape (e.g., star-shaped and/or branched) (ii) improving their stability, monodispersity, chemical miscibility, and activity, (iii) avoiding their aggregation and oxidation over time, (iv) increasing their yield and purity. The bottom-up approach, where the metal ions are reduced in the NPs grown in the presence of capping ligands, has been widely used compared to the top-down approach. Besides the physical and chemical synthesis methods, the biological method is gaining much consideration. Indeed, several drawbacks have been reported for the synthesis of NPs via physical (e.g., irradiation, ultrasonication) and chemical (e.g., electrochemisty, reduction by chemicals such as trisodium citrate or ascorbic acid) methods (e.g., cost, and/ortoxicity due to use of hazardous solvents, low production rate, use of huge amount of energy). However, (organic or inorganic) eco-friendly NPs synthesis exhibits a sustainable, safe, and economical solution. Thereby, a relatively new trend for fast and valuable NPs synthesis from (live or dead) algae (i.e., microalgae, macroalgae and cyanobacteria) has been observed, especially because of its massive presence on the Earth's crust and their unique properties (e.g., capacity to accumulate and reduce metallic ions, fast propagation). This article discusses the algal-mediated synthesis methods (either intracellularly or extracellularly) of inorganic NPs with special emphasis on the noblest metals, i.e., silver (Ag)- and gold (Au)-derived NPs. The key factors (e.g., pH, temperature, reaction time) that affect their biosynthesis process, stability, size, and shape are highlighted. Eventually, underlying molecular mechanisms, nanotoxicity and examples of major biomedical applications of these algal-derived NPs are presented.
\end{abstract}


Keywords: algal nanotechnology; nanoparticle biosynthesis; metallic nanoparticles; nanomedicine; translational medicine; sustainable technology

\section{Introduction}

Nanotechnology is a vibrant, revolutionary, and fast-developing multidisciplinary field that deals at nanoscopic scale $\left(10^{-9} \mathrm{~m}\right)$, impacting the environment, health, and socio-economy for more than two decades [1-4]. The resulting (natural, engineered or incidental) nanomaterials (e.g., nanoparticles (NPs)) usually display a dimension below $100 \mathrm{~nm}$ along with unique physical-chemical-biological properties (e.g., large surface-to-volume ratio, surface functionalization, controlled targeting and release) compared to their counterpart bulk materials. These interesting features make them incredibly attractive tools for applications in various fields (e.g., cosmetology, pharmacy, biotechnology, chemistry, or agriculture).

Actually, metal and non-metal NPs synthesized from plants (e.g., seaweeds) and microorganisms (e.g., bacteria) have attained more attention than classical physical and chemical synthesis routes mainly because of their (i) green assembly during the biosynthesis that uses clean energy processes regulated naturally, which subsequently overcomes the health and environmental toxicity; (ii) various attributes that contrast with those of them in the massive structure; (iii) peerless characteristics that drastically depend on the type (e.g., morphology/shape, size distribution, composition, and stability) and the dose, which can both impact on toxicity; (iv) cost-effectiveness; (v) eligibility for usage in a wide range of activities encompassing cosmetics, theranostics, food and textile fields [1-4].

Importantly, a recent trend of biologically synthesizing NPs using algal species (e.g., Chlorophyceae (green), Phaeophyceae (brown), Cyanophyceae (blue green), Rhodophyceae (red), Diatoms) is developing [5]. This tremendous and increasing interest is mainly due to the (i) ease of handling algae; (ii) capacity of algae to absorb/accumulate inorganic metallic ions; (iii) alternative strategy for cost-effective synthesis; and (iv) naturally eco-friendly, fast and healthier synthesis methods [5].

Algae represent an autotrophic (i.e., producers of their own food using light, water, carbon dioxide, or other chemicals) and polyphyletic (i.e., large and diverse) group of photosynthetic eukaryotic organisms. They are classified as microalgae (unicellular such as diatoms or multicellular) and macroalgae (seaweeds), primarily based on their morphological features, and can be found in marine and freshwater environments or over moist rocks [6]. These aquatic plants are simple and non-flowering. Indeed, although algae contain chlorophyll, they are lacking various structures (e.g., true stems, roots, leaves, and vascular tissue) that characterize the land plants (e.g., bryophytes, tracheophytes) [7]. Even so, they play a key role in the aquatic ecosystems (outside of their possible toxic blooming, which, interestingly, can be controlled by algal-mediated NPs) and represent an economically valuable biomass source for various applications (e.g., agricultural, aquacultural, pharmaceutical, cosmetical, biotechnological, energetical, and nanotechnological) [8,9].

This article mainly reports key factors and methods used in the algal-mediated synthesis of NPs. It also highlights (potential) biomedical applications, underlying molecular mechanisms and nanotoxicity of algal-mediated synthetized metallic NPs, with a special emphasis on AgNPs and AuNPs. Eventually, this review aims to contribute to the development of safe and sustainable nanotechnology from aquatic ecosystems.

\section{Types of Nanoparticles and Applications}

There are two kinds of NPs that can be synthesized using algae: the organic and inorganic ones.

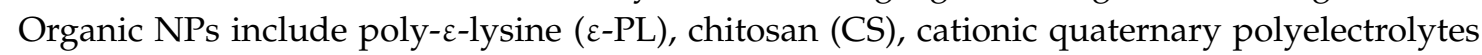
and quaternary ammonium compounds. Generally, these organic NPs are weakly stable at high temperatures compared to that of inorganic NPs, favoring inorganic NPs as antimicrobial polymers [10]. Even so, $\varepsilon$-PL is a L-lysine cationic homopeptide which is very efficient against Gram-positive bacteria 
and spores of B. coagulans, B. subtilis, and B. stearothermophilus [11,12]. CSNPs possess a wide spectrum of antimicrobial activity against viruses, bacteria, and fungi. They are nontoxic, biocompatible and can serve as absorption enhancers $[13,14]$. Cationic quaternary polyelectrolytes represent by-products of acrylic and methacrylic compounds. Due to their structural versatility, these molecules have a broad variety of biological applications (e.g., as antimicrobials) when factors such as their hydrophobicity, surface charge, molecular weight are altered [15]. Quaternary ammonium compounds are eminent disinfectants and rely on chain length for their antimicrobial properties [16]. Interestingly, the synthesis of organic NPs by algae has been poorly studied so far; This may be due to the lack of stability of the organic NPs at high temperature. Recently, Tiburu et al. (2017) investigated the formation of CSNPs by isolating deacetylated chitin from freshwater green algae [17]. The chitin was then converted into CS by mixing it with caustic soda and heating it by indirect steam. The resulting CSNPs were of an orthorhombic structure as revealed by $x$-ray powder diffraction (XRD) analysis.

Inorganic NPs, which include $\mathrm{Ag}$, zinc oxide $(\mathrm{ZnO})$, copper oxide $(\mathrm{CuO}), \mathrm{Au}$, and iron oxide (magnetite $\mathrm{Fe}_{3} \mathrm{O}_{4}$ and/or its oxidized form maghemite $\gamma-\mathrm{Fe}_{2} \mathrm{O}_{3}$ ), are the focus of this article. Metal NPs are the most studied nanomaterials because they display unique catalytic, electronic, and optical properties [18]. They also offer ease in controlled synthesis and surface modification, which allows tuning their size and shape-dependent properties [18]. It is now established that AgNPs possess strong antimicrobial properties against many fungi, viruses and bacteria because of their action as a photocatalyst and the capability to produce reactive oxygen species (ROS) [19-22]. ZnONPs are low cost antibacterial agents that can restrict the growth of a wide array of pathogenic bacteria [23]. They show anti-biofilm activity and can also block UV-rays, thus representing an effective coating material in medical and food materials [24]. CuONPs are used as antibacterial agents but they are less efficient than AgNPs or ZnONPs [25]. Their antibacterial activity is exerted through their capacity to disrupt cell membranes and produce ROS [26]. AuNPs are considered as non-toxic and are mainly used for gene delivery applications, biosensing and cancer therapy [27-29]. Iron oxide NPs are much applied in magnetic resonance imaging (MRI), immunoassays, tissue repair, and as effective agents in chemotherapy [30,31].

\section{General Methods for Synthesizing Nanoparticles with Tailored Properties}

NPs synthesis can follow two different pathways by using either the technique "bottom-up" or by applying the technique "top-down". The "bottom-up" technique is also called the self-assembly method because the initial synthesized NPs combine to form a structure or cluster by using chemical or biological methods. In "top-down" technique (e.g., ion etching, lithography), an appropriate bulk content is reduced to fragments using either chemical or physical processes.

NPs obtained from the "bottom-up" method (e.g., chemical/physical vapor deposition, electrochemistry) are preferred since they display more homogenous chemical composition and lesser defects than those resulting from "top-down" methods that elicit imperfect surface structures. These defected surface structures can have harmful impacts on the physical and chemical properties of NPs [32].

Wet-chemical processes are commonly used methods for synthesizing NPs, and implicate that NPs are grown in liquid media in the presence of several reactants, reducing and stabilizing/protecting agents (e.g., capping agents/ligands). Typically, NPs are synthesized by chemical reduction either by organic or inorganic reducing agents, via the colloidal route or by sol-gel method [32-34]. Although these methods yield high production of NPs at a low cost, they also contain some drawbacks (e.g., use of hazardous solvents, processing of harmful by-products and contamination from precursor chemicals) [32].

Physical synthesis of NPs involves various methods such as ultrasonication, electron beam, ion implantation, laser radiation, spray pyrolysis and vapor phase [34]. However, these physical methods have some drawbacks that make them less suitable for synthesizing NPs (e.g., high cost, low production rate, use of a huge amount of energy for maintaining the high temperature and pressure) [32]. 
To eliminate the drawbacks of physical and chemical methods used in the synthesis of NPs, an increasing interest is observed for green NPs synthesis using biological entities (e.g., microorganisms including bacteria, fungi, and yeast, microalgae or plant extracts including from macroalgae), which are considered as safe for health while minimizing the scarcity of energy resources [5,32].

Eventually, the choice of preparation procedure not only shall depend on the physical and chemical characteristics required on the final product (e.g., size (usually < $100 \mathrm{~nm}$ ), dispersion, shape (e.g., spherical, star-shaped, or branched NPs), chemical miscibility, optical properties (surface plasmon resonance (SPR) effect), but also shall consider environmental aspects.

\section{Key Factors Governing Nanoparticles Synthesis}

Several chemical, physical, and biological controlling factors are responsible for the proper, efficient, and optimal NPs (bio)synthesis process. These include $\mathrm{pH}$, temperature, metal ion concentrations, reactant concentrations, reaction time, stirring rate, incubation time, capping agents, and the type of microorganism or plant extract used. Most of these factors, if not all, can have an impact on the stability, size, and shape of the NPs. Besides, it is well known that the toxicity of nanomaterials essentially depends on the structural features such as the size, shape, composition, and surface chemistry.

\section{1. $p H$}

During the NPs synthesis reaction, the buffer strength (i.e., $\mathrm{pH}$ ) must be stable to avoid varying shapes and sizes of NPs [35]. At low $\mathrm{pH}$, the SPR peak becomes wide and deflects towards a longer wavelength region which results in a wide range of NPs (e.g., mainly cylindrical or triangular shaped), whereas for synthesizing small-sized NPs, high $\mathrm{pH}$ is suitable which aids the formation of spherical NPs [5]. Thereby, Ghaemi et al. (2017) observed the effect of $\mathrm{pH}$ by varying it from 2 to 10 during the formation of AgNPs when the extract of the brown macroalgae, Sargassum angustifolium (C.Agardh) was used [36]. Interestingly, these NPs displayed different stabilization power according to acidic or alkaline microenvironments. Indeed, in alkaline conditions (e.g., $\mathrm{pH} 10$ ), a reasonable number of very stable small-sized NPs were formed compared to that of in acidic conditions. In a more recent study, these observations were partially confirmed by Shou et al. (2011) that illustrated the formation of AuNPs in acidic and alkaline conditions by using triblock copolymers of PEO-PPO-PEO in aqueous media. Under alkaline conditions, many large-pearl-sized NPs were formed and were much more stable than the clustered NPs formed in acidic conditions [37,38].

\subsection{Temperature}

Temperature is another critical factor that governs the synthesis of NPs. The reaction temperature highly influences various chemical methods (e.g., solvothermal, electrochemical or templating methods) [39]. Generally, the NPs synthesis through green methodologies require a temperature of almost $100{ }^{\circ} \mathrm{C}$ [40]. Temperature higher than $350^{\circ} \mathrm{C}$ is required for physical methods whereas low temperatures are required for chemical synthesis [5,41]. Studies showed that high rate of AuNPs formation was observed at high temperature, which could be explained by a faster reduction rate [36]. However, their average size decreased when their conversion rate increased [35].

\subsection{Reactant Concentration}

Varying concentrations of biomolecules in a plant extract can have a different influence on NPs formation [35]. Thereby, Chandran et al. (2006) investigated the effect of reducing agent concentration in the reaction mixture on the yield and size of Au nanotriangles synthetized by Aloe vera (L.) leaf extract used as the reducing agent [42]. Monitoring the formation of Au nanotriangles as a function of time using transmission electron microscopy (TEM) reveals that multiply twinned particles (MTPs) play an important role in the formation of Au nanotriangles. It was also observed that the slow rate of the reaction along with the shape directing effect of the constituents of the extract are responsible for the formation of single crystalline Au nanotriangles. 
Furthermore, it was observed that when extract concentrations (up to 20\%) of the marine green macroalga Caulerpa serrulata (Forsskål) were added to a constant concentration of silver nitrate $\left(\mathrm{AgNO}_{3}\right)$ solution at room temperature, the SPR band intensity was increased while a decrease in average size of AgNPs was obtained [43]. However, a further increase in the extract concentration (from $20 \%$ to $25 \%$ ) reduced the SPR band intensity, but this effect was explained by a possible particle agglomeration.

\subsection{Reaction Time}

Reaction time is a crucial factor in the synthesis of NPs. Indeed, performing the same experiment by changing the reaction time may result in different particle sizes. For instance, Ahmad et al. (2012) biosynthesized the NPs by using Ananas comosus (L.) extract, which started to appear in $2 \mathrm{~min}$ and when the process was extended for $5 \mathrm{~min}$, spherical NPs were formed with a mean size of $12 \mathrm{~nm}$ [44]. Additionally, Aboelfetoh et al. (2017) showed that the gradual increase in contact time/interaction between Caulerpa serrulata (Forsskål) and silver ion $\left(\mathrm{Ag}^{+}\right)$at room temperature leads to an increase in SPR peak intensity and a rapid synthesis of non-agglomerated AgNPs [43]. Moreover, Prathna et al. (2011) investigated the growth kinetics of AgNPs as synthesized on a reduction of silver nitrate $\left(\mathrm{AgNO}_{3}\right)$ solution by aqueous extract of Azadirachta indica (Neem tree) leaves [45]. The reaction was continued for up to $4 \mathrm{~h}$ and analyzed by Ultraviolet-Visible (UV-Vis) spectrometry. The first peak of UV-Vis spectrum appeared after the first $2 \mathrm{~h}$ revealing NPs with particle sizes ranging from 10 to $35 \mathrm{~nm}$. The XRD pattern obtained after $2 \mathrm{~h}$ showed that the NPs were spherical with particle sizes around $20 \mathrm{~nm}$. As the time proceeds at almost $4 \mathrm{~h}$, the micrograph showed NPs with an average size of $36.6 \mathrm{~nm}$.

\subsection{Capping Agent}

As briefly mentioned earlier, basic procedures used for the preparation of protected or unprotected metallic NPs include colloidal chemistry methods (e.g., AuNPs synthesis by reduction with trisodium citrate, ascorbic acid, or sugars in aqueous phase; NPs passivation with alkanethiols, cetyltrimethylammonium bromide, or bovine serum albumin), as well as techniques such as microwave-assisted synthesis, NPs synthesis in ethylene glycol, and template-assisted synthesis with dendrimers [46]. The bottom-up approach where the metal ions are reduced by the reducing agent and the NPs grown in the presence of capping ligands has been widely used [18].

The biggest obstacle of using metal NPs could be their tendency to aggregate over time, which usually leads to a deterioration in their overall activity [18]. Thus, the stability of metal NPs against aggregation and oxidation should be adequately enhanced, including by using organic protecting ligands for which the head group interacts with a strong affinity to metal NP surfaces to stabilize the highly reactive surface atoms [18]. It is postulated that the alkyl spacer between the head and the tail groups of the ligand provides a capping shell and controls the interparticle spacing [18]. In addition, the functional tail groups of the ligand play a crucial role in determining the surface reactivity and solubility of the NPs [18]. Importantly, it was found that the type of ligands (e.g., thiol, disulfide, ammonium, citrate) and the degree of ligand capping along with applied synthetic conditions could systematically alter the NPs size, NPs shape, ligand-metal ratio and directly influence the chemical and physical properties (e.g., optical and electronic) of metal NPs [18].

\subsection{Choice of the Organism}

According to Rai et al. (2013), cost-effective NPs biosynthesis depends not only on the above physical-chemical parameters but also on (i) the selection of the best organism according to important intrinsic properties such as the growth rate, biochemical pathways and enzyme activities; (ii) its inoculum size; (iii) the choice of biocatalysts, which is crucial to accelerate the rate of reaction (i.e., reduction), although this should be done carefully [47]. Biocatalysts may be used as whole cells, crude, or purified enzymes (e.g., NADH, NADPH, FAD). In this regard, living whole cells are preferred 
because these coenzymes are expensive and can be recycled during the pathway, besides proving their substantial effectiveness.

\section{Algal-Mediated Inorganic Nanoparticles Synthesis Methods}

As previously evoked, algae are rich in polymeric molecules (e.g., polysaccharides) and can hyperaccumulate heavy metal ions and remodel them into malleable forms by (bio) reduction process. Algal extracts typically consist of pigments (e.g., chlorophylls, carotenoids, phycobilins), carbohydrates, proteins, minerals, polyunsaturated fatty acids (PUFAs), and other bioactive compounds such as antioxidants (e.g., polyphenols and tocopherols) that may be used as stabilizing/capping and reducing agents [48]. Moreover, the phycosynthesis of NPs takes less time compared to that of their biosynthetic entities [49]. Due to these overall properties, live or dead algae are used as a model organism for the eco-friendly synthesis procedure of bionanomaterials, such as metallic NPs [50]. In this routine, the NPs formation is followed by UV-Vis absorption spectroscopy and TEM, while the functional groups involved in the bioreduction are studied by FTIR [50].

Algal-mediated synthesis of inorganic NPs, such as Ag and $\mathrm{Au}$, which are the most investigated noble metals to be used by the algal biomass for producing NPs, can be obtained by the three subsequent steps (Figure 1) [49]: (i) heating or boiling algal extract after mixing it with water or an organic solvent for a certain time period; (ii) preparation of molar ionic metallic solutions; (iii) exposure of the algal extract to the molar solution of the (noble) metal ion precursor in a flask under (or not) continuous stirring for a certain time period. It is worth noting that the final reaction results in a color change that determines the nucleation in which the adjacent nucleon particles bind together to form thermodynamically stable NPs of varying shapes and sizes [47]. For instance, Rajeshkumar et al. (2012) synthesized AgNPs by using aquatic brown alga, Turbinaria conoides (J.Agardh) [51]. The alga was first cleaned and made into fine powder. A specific amount of algal extract was then added into a metal precursor of $\mathrm{AgNO}_{3}$ solution and stored at ambient temperature under mechanical stirring. The change of color from brown to dark brown showed the formation of NPs, which displayed spherical morphology with a mean particle size of $96 \mathrm{~nm}$.

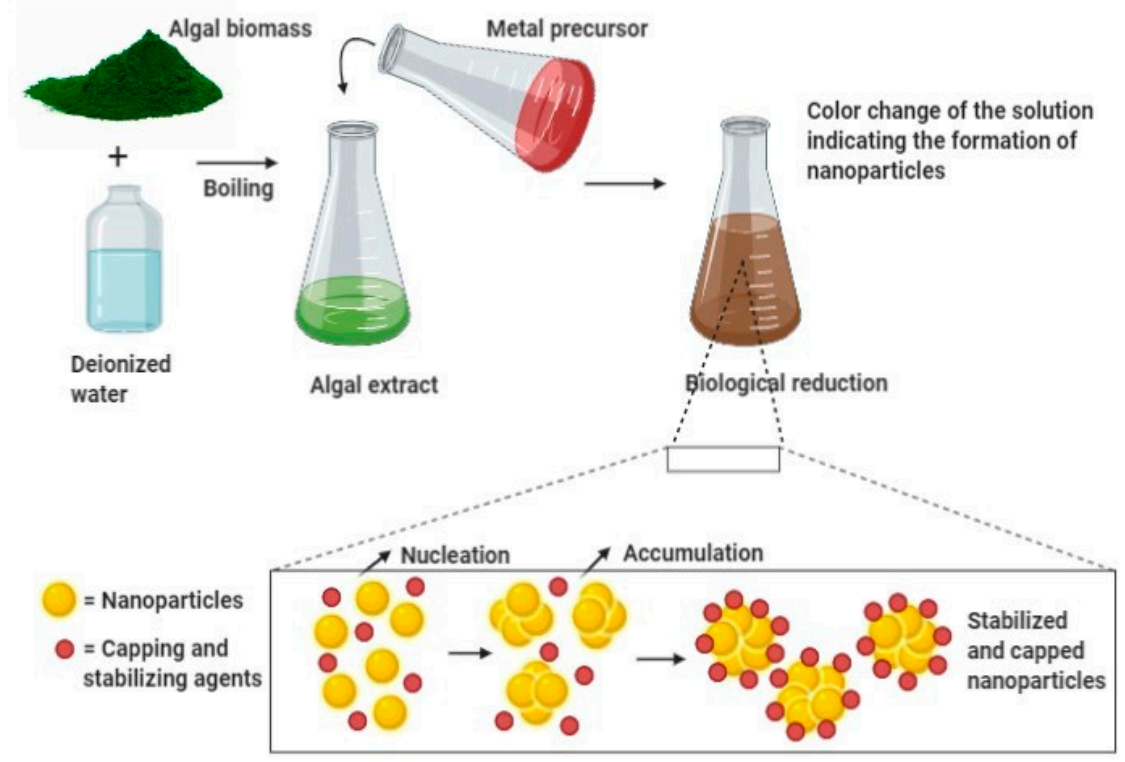

Figure 1. General mechanism for algal-mediated synthesis of inorganic/metallic nanoparticles.

Algal-mediated synthesis of inorganic NPs can either be achieved intracellularly or extracellularly [52]. In intracellular NPs synthesis, algal biomass is first collected and washed with distilled water. The biomass (live algae) is then treated with specific metallic solutions such as $\mathrm{AgNO}_{3}$ solution. The mixture is subsequently incubated at specific temperature, $\mathrm{pH}$, and time 
conditions for bioreduction. It is eventually sonicated and centrifuged to yield the harvested stable NPs. In extracellular synthesis of NPs, algal biomass is first collected and washed with distilled water. Then, the following three methods are commonly used for the further procedure: (i) the algal biomass (dead algae) is dried under shadow for a specific time and the dried powder is treated with distilled water and filtered out; (ii) the algal biomass is sonicated with distilled water to obtain a cell-free extract; or (iii) the algal biomass is washed with distilled water and incubated for a few hours (8-16 h) and the obtained product is then filtered.

Besides, in addition to the phycosynthesis of metallic NPs via an enzyme (intracellular nitrogenase)-mediated route for the metal (e.g., $\mathrm{Ag}$, $\mathrm{Au}$ ) reduction in cyanobacteria (e.g., Calothrix pulvinata) [53], recent studies report an innovative method, namely ultrasound irradiation-assisted synthesis (UIAS) of AgNPs and AuNPs, using the cyanobacteria Calothrix (C.Agardh ex Bornet \& Flahault) [54,55]. This eco-friendly and economical technique permits the acceleration of a wide range of chemical reactions and extraction procedures thanks to resulting cavitational collapses. Indeed, cavitational collapse produces intense local heating $\left(\sim 5000^{\circ} \mathrm{C}\right)$ and high pressures $(\sim 2000$ atmospheres $)$ in the liquid reaction mixture, with noticeably short lifetimes $[54,55]$.

In this illustration, algal biomass is first combined with deionized water and boiled at a certain temperature. The obtained algal extract is then treated with a metal precursor and incubated for a certain time at ambient temperature. The change of color indicates the formation of NPs. During the bioreduction of metal ions, the subsequent processes of nucleation and condensation (accumulation) assures the formation (growth) of stabilized NPs surrounded by capping agents. Then, several physical techniques can be used to characterize biosynthesized NPs. Thereby, the solution color change and SPR can be observed by UV-Vis spectroscopy, while the size, shape, and morphology of NPs can be determined by Dynamic Light Scattering (DLS) and/or Scanning Electron Microscopy (SEM) and/or TEM. In addition, their structure (functional groups) can be unraveled by FTIR spectroscopy, and their crystalline nature can be assessed by XRD spectroscopy.

\subsection{Methods of Microalgal-Mediated AgNPs Synthesis}

Jena et al. (2013) reported the synthesis of AgNPs using the microalga Chlorococcum humicola (Nägeli) that belongs to the class Chlorophyceae, a freshwater, autotrophic and colonial microscopic organism that elicits high biomass productivity with high growth rate, while requiring minimum amount of sunlight and atmospheric $\mathrm{CO}_{2}$ for growth, making it very convenient and useful for pharmaceutical and nutraceutical purposes [56]. In this study, AgNPs were prepared by in-vivo and in-vitro synthesis by exposing the silver salt $\left(\mathrm{AgNO}_{3}\right)$ solution at room temperature which caused the reduction of silver ion $\left(\mathrm{Ag}^{+}\right)$. During the in-vitro synthesis, the formation of AgNPs was detected by a solution color change from translucent to dark reddish-yellow due to the excitation of SPR vibrations with the $\mathrm{Ag}^{+}$whereas in in-vivo synthesis, the color change from bright green to dark brown is the indication of the formation of AgNPs. Both the in-vivo and in-vitro bioreduction synthesis systems confirm that AgNPs were randomly embedded in the cell surface of microalgae; they were evenly distributed throughout the algal biomass without agglomeration. The result from TEM analysis revealed that the AgNPs possessed a spherical shape with a crystalline structure and their sizes ranged from 2 to $16 \mathrm{~nm}$ with a mean size of 4 and $6 \mathrm{~nm}$ (Table 1 ).

More recently, Chokshi et al. (2016) investigated the biosynthesis of AgNPs using de-oiled biomass of Acutodesmus dimorphus (Turpin), a thermotolerant oleaginous microalga that has biofuel potential and displays antioxidant property [57]. This green alga is besides used as a biofertilizer and biostimulant [58]. In this study [57], the resulting AgNPs displayed antioxidant properties. The color change of the solution, from clear to brownish, indicated the development of AgNPs. The synthesized nanocrystals were of spherical morphology with a varying size from 2 to $15 \mathrm{~nm}$ as observed by atomic force microscopy (AFM) and TEM. 


\subsection{Methods of Macroalgal-Mediated AgNPs Synthesis}

Hashemi et al. (2015) reported the synthesis of AgNPs using the marine brown macroalga, Padina boergesenii (Allender \& Kraft) [59]. This leafy rolled-blade alga exhibits a wide range of features including antidiabetic, antifungal, enzyme inhibition, anti-inflammatory and anti-angiogenic activities [60-63]. Due to the reduction of $\mathrm{Ag}^{+}$in the algal solution and through a surface excitation plasmon vibration effect, the color of the solution turned into brownish yellow indicating the formation of AgNPs [59]. TEM micrographs demonstrated that AgNPs collected were crystalline in nature with spherical morphology and the particle size varied from 34.62 to $54.33 \mathrm{~nm}$ with the mean size of $43.3 \mathrm{~nm}$ (Table 1).

Similarly, Bhimba et al. (2015) investigated the biosynthesis of AgNPs using extract of Gracilaria corticata (J.Agardh) [64]. This red macroalga exerts potent activities including antioxidant, antifungal, and antibacterial properties and is applied in food colorants [65-68]. The bioreduction of $\mathrm{AgNO}_{3}$ solution resulted in a shift in color from clear to dark brown suggesting the development of AgNPs, which were spherical with particle sizes ranging from 10 to $35 \mathrm{~nm}$ as shown by TEM [64].

\subsection{Methods of Cyanobacterial-Mediated AgNPs Synthesis}

Mahdieh et al. (2012) showed extracellular formation of AgNPs by Arthrospira (formerly known as Spirulina) platensis (Gomont), a blue-green free-floating cyanobacterium mainly found in tropical and subtropical areas [69]. S. platensis is characterized mainly by cylindrical, multicellular trichomes, and displays heavy carbonate and bicarbonate ion concentrations [69]. This cyanobacterium is a potent protein source, animal feed supplement, and exerts antitumor, antioxidant and anti-inflammatory activities [70-72]. During the exposure of algal biomass, reduction of $\mathrm{Ag}^{+}$ions occurred and consequent formation of AgNPs was indicated by a color change of solution from yellowish brown to dark brown [69]. TEM analysis showed that AgNPs were crystalline with a size ranging from 5 to $30 \mathrm{~nm}$ with a mean size of approximately $12 \mathrm{~nm}$ (Table 1 ).

Singh et al. (2014) performed the biosynthesis of AgNPs using the nitrogen-fixing cyanobacterium Anabaena doliolum (Bharadwaja) [73]. This filamentous freshwater species exerts antibacterial and antitumor activities and possesses unique features like salt tolerance and protection to nitrogenase activity. The bioreduction of $\mathrm{Ag}^{+}$solution resulted in a shift in color from reddish blue to dark brown, indicating the formation of AgNPs) [73]. TEM micrographs showed well-dispersed spherical AgNPs with a particle size ranging between 10 and $50 \mathrm{~nm}[73,74]$. 
Table 1. Algae-mediated synthesis of silver nanoparticles (AgNPs). (Copyright permission has been granted for each figure).

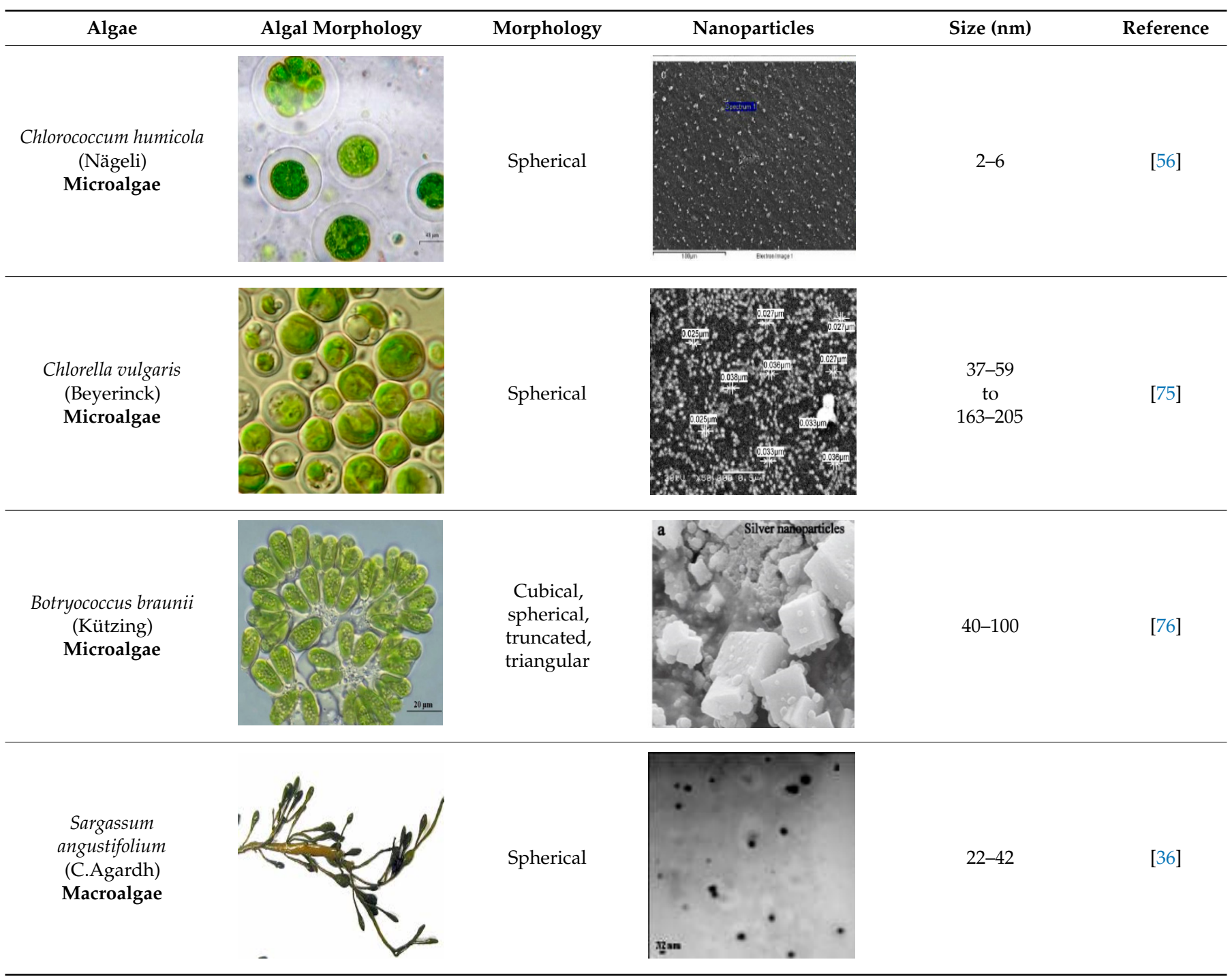


Table 1. Cont.

\begin{tabular}{|c|c|c|c|c|c|}
\hline Algae & Algal Morphology & Morphology & Nanoparticles & Size $(\mathrm{nm})$ & Reference \\
\hline $\begin{array}{c}\text { Sargassum muticum } \\
\text { (Yendo) } \\
\text { Macroalgae }\end{array}$ & & Spherical & & $5-15$ & [77] \\
\hline $\begin{array}{c}\text { Cystophora moniliformis } \\
\text { (Esper) } \\
\text { Macroalgae }\end{array}$ & & $\begin{array}{c}\text { Spherical, } \\
\text { polydispersed }\end{array}$ & & 81 & [78] \\
\hline $\begin{array}{l}\text { Ulva fasciata } \\
\text { (Delile) } \\
\text { Macroalgae }\end{array}$ & & Crystalline & & 33 & [79] \\
\hline $\begin{array}{c}\text { Pithophora oedogonia } \\
\text { (Mont.) } \\
\text { Macroalgae }\end{array}$ & & $\begin{array}{c}\text { Cubical, } \\
\text { sometime } \\
\text { hexagonal }\end{array}$ & 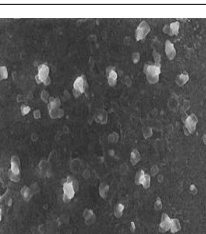 & $25-44$ & [80] \\
\hline
\end{tabular}


Table 1. Cont.

\begin{tabular}{|c|c|c|c|c|c|}
\hline Algae & Algal Morphology & Morphology & Nanoparticles & Size (nm) & Reference \\
\hline $\begin{array}{c}\text { Padina boergesenii } \\
\text { (Allender \& Kraft) } \\
\text { Macroalgae }\end{array}$ & & Spherical & & $34-54$ & [59] \\
\hline $\begin{array}{l}\text { Spirulina platensis } \\
\text { (Gomont) } \\
\text { Cyanobacterium }\end{array}$ & & Cubic & & 12 & [69] \\
\hline
\end{tabular}




\subsection{Methods of Microalgal-Mediated AuNPs Synthesis}

Shakibaie et al. (2010) reported the synthesis of AuNPs using Tetraselmis suecica (Kylin), a green marine microalga [81]. In this study, the algal extract reduced gold ions ( $\mathrm{Au}^{3+}$ or Gold (III)) to AuNPs in the presence of chloroauric acid $\left(\mathrm{HAuCl}_{4}\right)$. The resulting formation of AuNPs by this simple and cheap process was indicated by the color change of $\mathrm{HAuCl}_{4}$ solution from yellow to ruby red [81]. TEM analysis showed that the synthesized AuNPs were crystalline in nature, spherical, did not aggregate, and displayed an average particle size of $79 \mathrm{~nm}$ (Table 2).

Besides, Dahoumane et al. (2012) investigated the biosynthesis of AuNPs by the microalga Klebsormidium flaccidum (Kützing) [82]. This species possesses a unique feature of tolerating abiotic stresses such as cold acclimation, and can increase the osmotic concentrations of cells when submerged in hypertonic artificial water (e.g., after incorporating sucrose and amino acids) [82]. The color change of solution from yellow to purple, after bioreduction of $\mathrm{Au}^{3+}$, indicated the formation of AuNPs [82]. TEM analysis showed that the AuNPs were spherical and the size was about $9.0 \pm 3.4 \mathrm{~nm}$ [82].

\subsection{Methods of Macroalgal-Mediated AuNPs Synthesis}

Singaravelu et al. (2007) reported the use of the brown macroalga, Sargassum wightii (Greville), for biosynthesis of AuNPs This seaweed is rich in sulfated polysaccharides and exerts a wide spectrum of biological properties such as free scavenging and antioxidant effects [83]. Biosynthesis process of AuNPs implicated the use of $\mathrm{HAuCl}_{4}$ and a change in color from yellow to ruby red after reduction of $\mathrm{Au}^{3+}$ [83]. TEM micrographs showed monodispersed AuNPs, ranging from 8 to $12 \mathrm{~nm}$, with an average size of $11 \mathrm{~nm}$ (Table 2).

Singh et al. (2012) investigated the synthesis of AuNPs using the brown seaweed Padina gymnospora (Kützing) [84]. This macroalgae is known for its potent antioxidant, antibacterial and wound healing properties [84]. During the AuNPs synthesis, the bioreduction of $\mathrm{Au}^{3+}$ occurred in the presence of the algal biomass, and this was confirmed by the color change of the solution from yellow to ruby red [84]. SEM analysis showed that the synthesized AuNPs were spherical-shaped with a particle size between 53 and $67 \mathrm{~nm}$ [84].

Venkatesan et al. (2014) reported biosynthesis of AuNPs by reduction of $\mathrm{Au}^{3+}$ using the novel edible marine brown macroalga Ecklonia cava (Kjellman) [85]. Synthesized AuNPs showed good antimicrobial and biocompatibility with human keratinocyte cell line [85]. Interestingly, the reaction was completed within $1 \mathrm{~min}$ at $80^{\circ} \mathrm{C}$ [85]. Further, FTIR spectroscopy revealed that AuNPs were functionalized with biomolecules that have primary amine group, hydroxyl group and other stabilizing functional groups [85]. Additionally, XRD pattern showed high purity and face-centered cubic structure of the AuNPs [85]. Eventually, microscopy results showed that these AuNPs were formed with shapes (e.g., spherical and triangular) with an average size of $30 \pm 0.25 \mathrm{~nm}$ [85].

\subsection{Methods of Cyanobacterial-Mediated AuNPs Synthesis}

Kalabegishvili et al. (2012) reported the extracellular synthesis of AuNPs using the blue-green alga, S. platensis (Gomont) [86]. As previously described, this multicellular filamentous helical cyanobacterium is often used as a medicinal matrix and food additive [86]. Interestingly, the biosynthesis process of AuNPs from S. platensis is simple, rapid, economical, and involves bioreduction of $\mathrm{Au}^{3+}$. The resulting AuNPs were mostly of spherical morphology, some of the NPs also showed face-centered cubic structures, and their size ranged from 15 to $60 \mathrm{~nm}$ with an average size of $30 \mathrm{~nm}$, as seen by TEM analysis (Table 2).

Lenartowicz et al. (2017) investigated the biosynthesis AuNPs with various shapes using the filamentous cyanobacterium, Anabaena laxa (Rabenhorst) [87]. The reaction was performed by taking low concentrations of $\mathrm{HAuCl}_{4}$ to avoid death of this sensitive cyanobacterium [87]. After bioreduction of $\mathrm{Au}^{3+}$, the color of the solution changed from transparent to purple indicating the formation of AuNPs [87]. The TEM analyses of the obtained AuNPs revealed variable morphology (e.g., spherical, 
triangular, hexagonal, and irregular shape), and the particles size mostly ranged between 0 and $30 \mathrm{~nm}$ although few larger NPs ranged in size between 30 and $100 \mathrm{~nm}$ [87].

Table 2. Algal-mediated synthesis of gold nanoparticles (AuNPs). (Copyright permission has been granted for each figure).

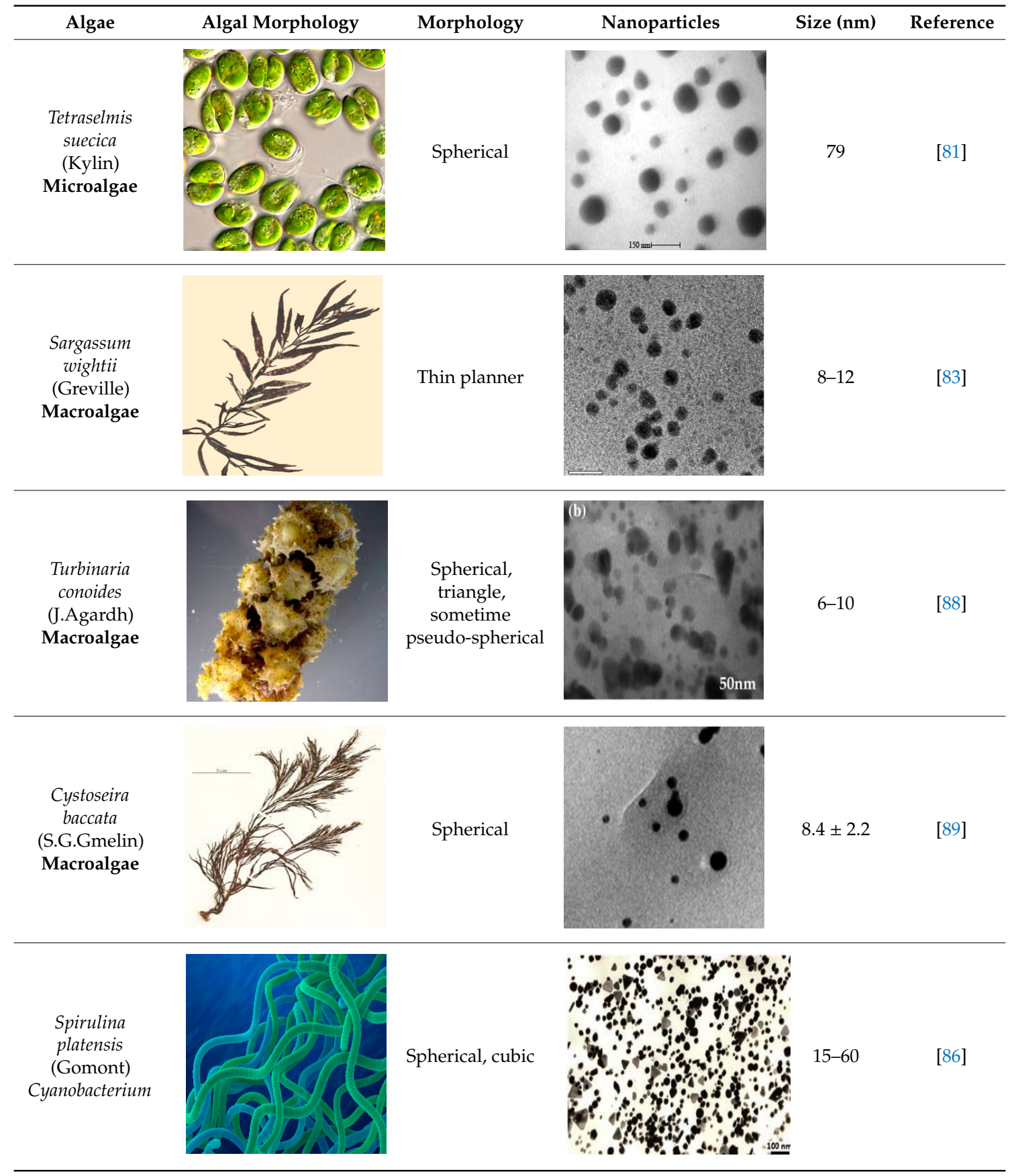

Kumar et al. (2016) demonstrated the accelerated, high product yield, and cost-effective synthesis of AuNPs by the simple UIAS in an ecofriendly manner using the cyanophyceae Calothrix [54]. The appearance of a light pink color at $\lambda_{\max }=550 \mathrm{~nm}$ indicated the synthesis of AuNPs [54]. The XRD spectrum of the AuNPs exhibited a Bragg reflections peak at 38.23, corresponding to the elemental gold [54]. TEM images showed the formation of anisotropic AuNPs with predominant truncated shape and particles are in the range of 30-120 nm [54]. Further, AuNPs showed significant 
catalytic efficiency in reducing 4-nitrophenol to 4-aminophenol, proving its potential usefulness in remediation of toxic chemicals and other catalyst based industrial applications [54].

\subsection{Algal-Mediated Synthesis of Other Types of Nanoparticles}

The algal-mediated synthesis of metallic NPs other than AgNPs and AuNPs is also possible by reduction of metal ions $\left(\mathrm{Ag}^{+}\right.$or $\left.\mathrm{Au}^{+}\right)$[53]. Indeed, different NPs such as cadmium sulfide (CdS), $\mathrm{CuO}$, iron oxide $\left(\mathrm{Fe}_{2} \mathrm{O}_{3}\right)$, palladium (Pd) and $\mathrm{ZnONPs}$ can be prepared either from microalgae, macroalgae or cyanobacteria (Figure 2A-E).

Thereby, CdSNPs could be synthetized by using the cyanobacterium Phormidium tenue (Gomont), which is known to exhibit special photochemical and photophysical properties [90]. The bioreduction reaction of cadmium ions $\left(\mathrm{Cd}^{2+}\right)$ was monitored until the color changed from yellow to orange, which indicated the formation of CdSNPs [90]. TEM analysis showed that these NPs were spherically shaped with a mean particle size of $5 \mathrm{~nm}$ (Figure 2A).

Another study led by Mandal et al. (2016) showed the algal-mediated synthesis of CdSNPs using S. platensis (Gomont) that was initially cultured in the laboratory at ambient temperature [91]. After harvesting and shade drying in petri plates, the pellets were homogenized with liquid $\mathrm{N}_{2}$ in an autoclaved mortar for extraction. The obtained mixture was then centrifuged for $20 \min$ at $4{ }^{\circ} \mathrm{C}$ and the supernatant was stored for further analysis. Cadmium nitrate $\left(\mathrm{Cd}\left(\mathrm{NO}_{3}\right)_{2}\right)$ solution was added to the algal mixture for the synthesis of CdSNPs and yellow color appearance confirmed the formation of CdSNPs [91]. The TEM image showed that the synthesis was intracellular and the NPs were spherical in shape with an average diameter of 8-12 nm [91].

Besides, CuONPs could be prepared using an extract of the brown macroalga, Bifurcaria bifurcate (R.Ross), which is known to exert antimicrobial, antioxidant and antitumoral activities [92]. The biosynthesized CuONPs were observed by a color change, classically due to the SPR phenomenon, from deep blue to dark red, after bioreduction of copper ions $\left(\mathrm{Cu}^{2+}\right)$ with water-soluble diterpenoids abundantly present in the algal extract [92]. From TEM micrographs, CuONPs exhibited a spherical morphology and a particle size ranging from 5 to $45 \mathrm{~nm}$, with a mean size of $20.66 \mathrm{~nm}$ (Figure 2B).

Another study led by Bhattacharya et al. (2019) reported the formation of CuONPs by using Anabaena cylindrica (Lemmermann) [93]. This filamentous photoautotrophic cyanobacterium is capable of fixing nitrogen [93]. The synthesized CuONPs were used as disinfectant for purifying drinking water and as an antimicrobial against pathogen strains of Escherichia coli [93]. These NPs were crystalline in nature as revealed by XRD and SEM pattern analyses [93]. Their average particle size was of $3.6 \mathrm{~nm}$ as measured by a zetasizer instrument [93].

Moreover, $\mathrm{Fe}_{3} \mathrm{O}_{4} \mathrm{NPs}$ have tremendous potential in many applications such as biosensors, environmental remediation, magnetic storage media, ferrofluids, and catalysts [94]. Indeed, $\mathrm{Fe}_{3} \mathrm{O}_{4} \mathrm{NPs}$ possesses a cubic inverse spinel structure that exhibit unique electric and magnetic properties [94]. Interestingly, these NPs were synthesized by Mahdavi et al. (2013) using an aqueous extract of the invasive/fast-growth-rate seaweed Sargassum muticum (Yendo), commonly known as Japanese wireweed [94]. During the biosynthesis reaction and after the bioreduction of ferric ions $\left(\mathrm{Fe}^{3+}\right)$ using ferric chloride $\left(\mathrm{FeCl}_{3}\right)$ as a metal precursor, the rapid color change of the solution from yellow to dark brown indicated the formation of $\mathrm{Fe}_{3} \mathrm{O}_{4} \mathrm{NPs}$ [94]. TEM analysis showed that these NPs were cubic and presented a particle mean size of $18 \pm 4 \mathrm{~nm}$ (Figure 2C).

Another study led by El-Kassas et al. (2016) reported the synthesis of $\mathrm{Fe}_{3} \mathrm{O}_{4} \mathrm{NPs}$ using two brown seeweeds: Padina pavonica (Linnaeus) and Sargassum acinarium (Linnaeus) [95]. The samples were washed to remove contaminants, dried at $-20{ }^{\circ} \mathrm{C}$ and then ground to powdered form. $\mathrm{Fe}_{3} \mathrm{O}_{4} \mathrm{NPs}$ were then prepared by co-precipitation method [95]. Briefly, $\mathrm{FeCl}_{3}$ solution was added to the algal extract and NPs were obtained by reduction process. The mixture was then stirred and centrifuged. The color change from yellow to brown indicated the synthesis of $\mathrm{Fe}_{3} \mathrm{O}_{4} \mathrm{NPs}$. TEM image showed spherical NPs in size range of $10-19.5 \mathrm{~nm}$ for P. pavonica and 21.6-27.4 $\mathrm{nm}$ for S. acinarium [95]. 
Furthermore, PdNPs were made by Momeni et al. (2015) using the brown marine macroalga Sargassum bovinum (C.Agardh), which is known to display electrocatalytic activities towards $\mathrm{H}_{2} \mathrm{O}_{2}$ [96]. Due to the presence of water-soluble compounds in the algal extract, the reduction of palladium ions $\left(\mathrm{Pd}^{2+}\right)$ to PdNPs occurred with color changes in the solution from yellow to dark brown [96]. The resulting synthesized NPs displayed a mean particle size of 5-10 nm with octahedral morphology as shown by TEM analysis (Figure 2D).

In addition, Sayadi et al. (2018) investigated the biosynthesis of PdNPs by the filamentous Gram-negative cyanobacterium S. platensis (Gomont) [97]. After bioreduction of $\mathrm{Pd}^{2+}$, the color of the solution changed from yellow to dark brown, indicating the formation of PdNPs) [97]. The obtained NPs were spherical in shape with a particle size ranging from 10 to $20 \mathrm{~nm}$, as observed by TEM [97].

Eventually, Priyadharshini et al. (2014) investigated the extracellular synthesis of ZnONPs using extracts from the red macroalga, Gracilaria edulis (S.G.Gmelin) [98]. This agarophyte exerts a wide variety of activities including anti-viral, anti-cancer, anti-bacterial and anti-fungal [98]. After bioreduction of zin ions $\left(\mathrm{Zn}^{2+}\right)$ using zinc nitrate $\left(\mathrm{Zn}\left(\mathrm{NO}_{3}\right)_{2}\right)$ as metal precursor, a change of color from white to pale brown was observed, indicating the formation of ZnONPs [98]. The obtained NPs were rod-shaped with a particle size ranging from 66 to $95 \mathrm{~nm}$ [98].
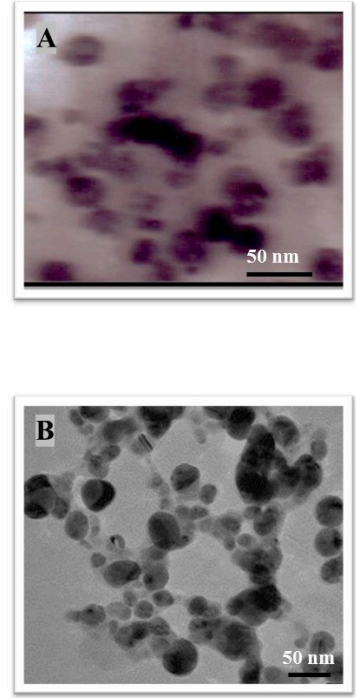
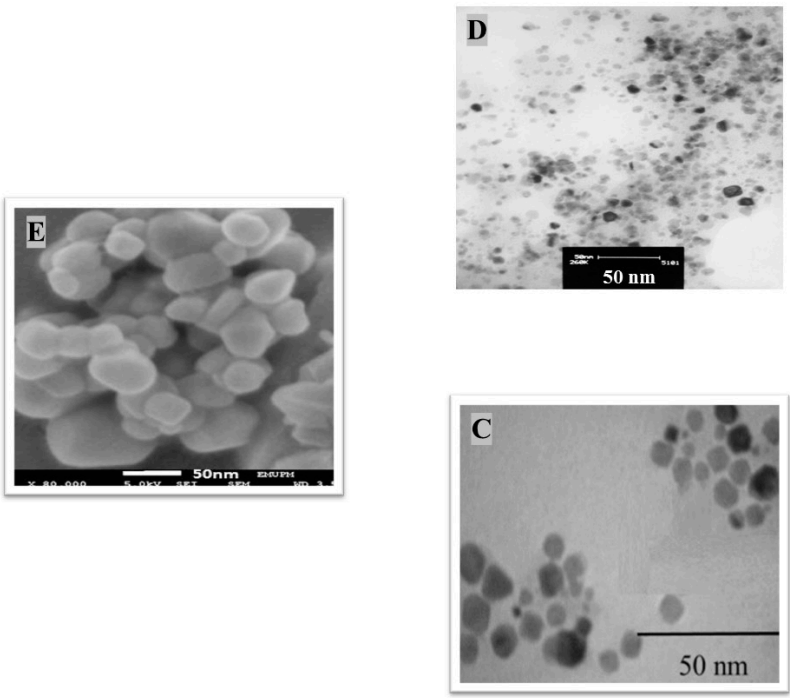

Figure 2. TEM images of various metallic nanoparticles (NPs). (A) Cadmium sulfide NPs (CdSNPs) by Phormidium tenue [90], (B) copper oxide NPs (CuONPs) by Bifurcaria bifurcata [92], (C) iron oxide NPs $\left(\mathrm{Fe}_{2} \mathrm{O}_{3} \mathrm{NPs}\right.$ ) by Sargassum muticum [94], (D) palladium NPs (PdNPs) by Spirulina platensis [97], (E) zinc oxide NPs (ZnONPs) by Sargassum muticum [99]. (Copyright permission has been granted for each figure).

Another study published in the same year by Azizi et al. (2014) reported such biosynthesis using an aqueous extract of the brown macroalga Sargassum muticum (Yendo), previously evoked for the biosynthesis of $\mathrm{Fe}_{2} \mathrm{O}_{3} \mathrm{NPs}$ [99]. After bioreduction of $\mathrm{Zn}^{2+}$, a change of color from dark brown to pale white, indicating the formation of ZnONPs [99]. These NPs were hexagonal shapes with a particle size ranging between 30 and $57 \mathrm{~nm}$ as noticed from SEM analysis (Figure 2E).

\section{Major Bioapplications and Underlying Molecular Mechanisms of Algal-Mediated Synthesis of Metallic NPs}

There are several applications reported for the algal-mediated synthesis of inorganic NPs. Metallic NPs and NPs, such as AgNPs and AuNPs, have been broadly considered for use in applications in a different scope of biotechnological, medical, cosmetical and pharmaceutical fields. The main applications of these NPs in the fields of medicine and biotechnology are illustrated in Figure 3. 


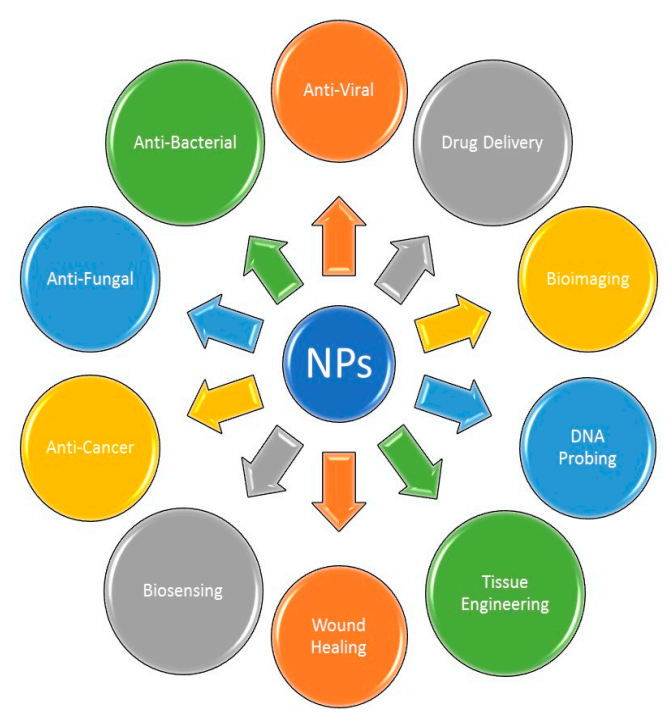

Figure 3. Major applications of metallic NPs.

The physicochemical reactivity of (metallic) NPs leads to oxidative stress due to the resulting formation of free radicals or ROS (e.g., superoxide radical anions and hydroxyl radicals) directly or indirectly (i.e., through activation of oxidative enzymatic pathways), as shown in Figure 4. Some metal oxide NPs, such as titanium dioxide NPs $\left(\mathrm{TiO}_{2} \mathrm{NPs}\right)$ used in cosmetics, food additives and cancer therapy, are water-insoluble but would induce enhanced toxicity effects (e.g., oxidative stress, phototoxicity, genotoxicity and immunotoxicity), especially at concentrations higher than $100 \mu \mathrm{g} / \mathrm{mL}$ [100]. Despite other NPs such as $\mathrm{ZnO}, \mathrm{TiO}_{2} \mathrm{NPs}_{\text {do }}$ not release toxic ions hence toxicity of these NPs (i.e., ROS, mitochondrial depolarization, plasma membrane leakage, intracellular calcium influx and cytokine release) could be attributed to their size-dependent interaction/adsorption with intracellular biomolecules [100]. Additionally, it was shown that phototoxicity of these NPs could be decreased via surface coating with CS because of the prevention of biomolecule adsorption and hydroxyl radicals $(\cdot \mathrm{OH})$ production in the photoactivation process [100].

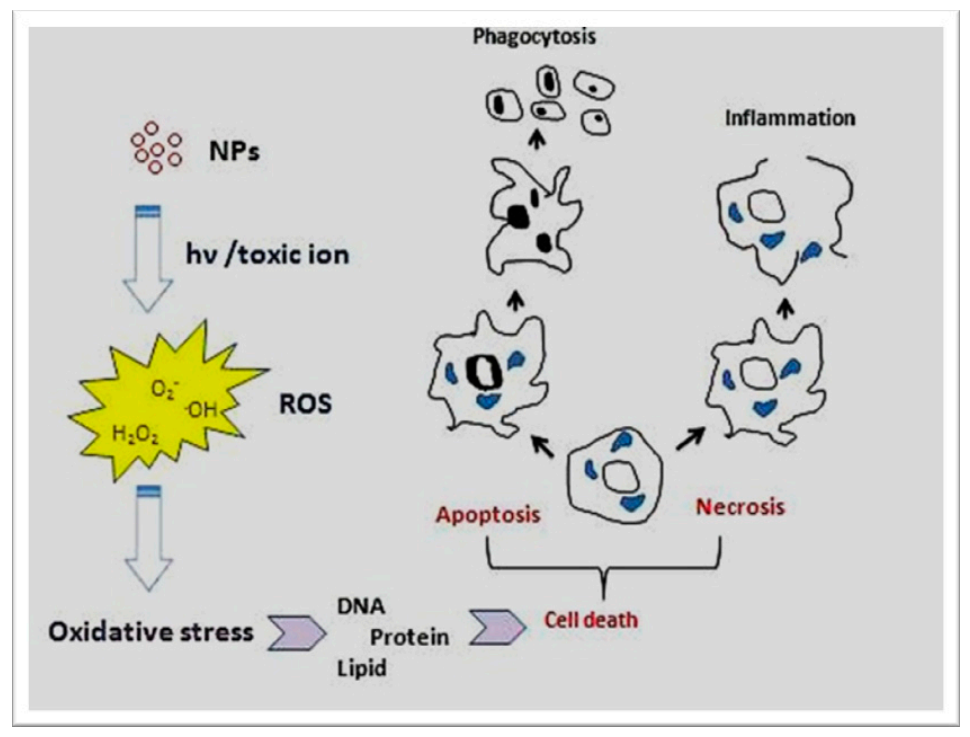

Figure 4. Major molecular and cellular mechanisms involved in the toxicity of (metallic) NPs [100]. (Reproduced with permission). 


\subsection{Some Medical Applications and Underlying Molecular Mechanisms of Algal-Mediated Synthetized AgNPs}

AgNPs possess good conductivity and are overly sensitive towards surface absorption of the metals. Thereby, AgNPs are often associated with many useful theranostic applications including biosensing, imaging, drug delivery, wound healing, cancer and microbial (e.g., bacteria, some fungi) therapies [2]. Due to the efficient antimicrobial properties, AgNPs are used in a broad spectrum of consumer products such as cosmetics, electronics, textiles, and food products [100].

For instance, topical ointments (e.g., creams) or implants impregnated with Ag polymers were conceived to avoid infections of burned and damaged areas, because AgNPs are known to cause cell membrane lysis of bacteria [2]. Furthermore, biosynthesized NPs can be used as efficient controlled and disease targeted drug-delivery systems if they are able to escape the immune system by overcoming biological barriers and the complex tumor microenvironment (TME) [101].

Interestingly, Khalid et al. (2017) reported anti-bacterial, anti-fungal, anti-cancerous and antiviral properties of AgNPs synthesized by ethanolic extract of three freshwater microalgae strains, namely HM1 (DHM1), HM2 (DHM2), both derived from Dictyosphaerium sp. (Nägeli), and HM3 (PHM3) from Pectinodesmus sp. (Meyen) [102]. Significant activity of these AgNPs was reported against 14 bacterial strains, the fungal strain Candida albicans, the hepatocellular carcinoma (HepG2) and breast cancer (MCF7) cell lines and against the Newcastle Disease Virus (NDV) on Huh7-infected cells [102]. Unfortunately, as an example of several studies, the underlying molecular mechanisms have not been mentioned in this published work.

Besides, Venkatesan et al. (2016) demonstrated that AgNPs, synthesized by extracts from brown seaweed Ecklonia cava (Kjellman), elicit a significant anti-bacterial activity against Escherichia coli and Staphylococcus aureus, as well as an efficient antioxidant activity in vitro, and an anti-cancer activity against human cervical (HeLa) cells by a mechanism involving apoptosis [103].

Considering the wide use of AgNPs in medicine, toxicity assay is an important factor to keep in mind. Cytotoxicity of these NPs, independently of their surface coating, is related to comfortable oxidation $\mathrm{AgNPs}$ to $\mathrm{Ag}^{+}$ions which are very toxic for biological systems and cellular components (e.g., DNA) [100]. It is postulated that AgNPs in an aqueous system are more toxic compared to the bulk. $\mathrm{Ag}$ is more toxic due to the presence of dissolved oxygen, its reduction on NPs and then the release of $\mathrm{H}_{2} \mathrm{O}_{2}$ from AgNPs [100]. Additionally, results demonstrated that ROS generation from AgNPs are greater than that of macro (bulk) silver, and those AgNPs with higher intracellular Ag release are also more toxic [100].

\subsection{Some Medical Applications and Underlying Molecular Mechanisms of Algal-Mediated Synthetized Gold Nanoparticles}

AuNPs are one of the most promising inorganic NPs that have attracted scientific and technological interests due to their ease of synthesis, chemical stability, and excellent optical and electronic properties [100]. These unique properties make them appealing tools for biomedical applications in radiology as radiation enhancer, in targeted-drug delivery, in biosensing for biomolecular hypersensitive detection (biosensing), in cancer diagnostics and cancer therapy by hyperthermal treatment [104].

The application of AuNPs in such fields depends primarily on the capacity to synthesize particles with regulated shape, monodispersity, size, stability, and chemical composition. Interestingly, they can be easily prepared by various methods (i.e., physical, chemical and the growing safe and effective biological approach) due to their exceedingly small diameter, and thereby can be easily transferred to tissues and cells just like DNA and proteins [105].

For instance, Murugesan et al. (2015) showed that the AuNPs, synthesized by the red macroalgae, Hypnea musciformis (Wulfen), which besides is known as a highly opportunistic invader causing large floating blooms, are able to exert anti-fungal properties against Aspergillus niger and Mucor spp. [106].

Whereas AgNPs have attracted much interest as antimicrobials, the development of AuNPs has largely contributed to a new field of research, namely cancer nanomedicine. This is because, in comparison to traditional anti-cancer drugs, NPs provide a targeted approach which prevents 
undesirable effects [105,107]. Thereby, González-Ballesteros et al. (2017) performed the synthesis of AuNPs using a brown alga Cystoseira baccata (S.G.Gmelin) [89]. The alga was washed with distilled water and the fragments were converted into fine pieces. The solution was then boiled and centrifuged at $4500 \mathrm{rpm}$ for $10 \mathrm{~min}$. Aqueous solution of $\mathrm{HAuCl} 4$ was added to the algal extract and kept at room temperature with stirring at regular intervals. The TEM analysis showed the formation of spherical gold nanoparticles with an average particle size of $8.4 \pm 2.2 \mathrm{~nm}$ (Table 2). The synthesized AuNPs were then tested against human colon cancer Caco-2 and HT-29 cells for which they showed a significant anticancer effect [89].

Although most of in vitro investigations have demonstrated that AuNPs are non-toxic for cells, their cytotoxicity depends on their uptake and intracellular distribution which themselves rely on the size and shape of AuNPs as well as on their surrounding ligands [100]. For instance, the cytotoxicity effects, observed with Balb/3T3 mouse fibroblasts treated with 5-nm AuNPs but not with 15-nm AuNPs, were explained by the high number of small AuNPs taken-up by cells in comparison to the larger particle [108]. It is stated that anisotropic AuNPs (e.g., (nanorods, nanourchins and nanocages) have more potential oxidation than the isotropic ones due to their highly exposed surface areas and defects [109]. In addition, some studies indicated that spherical AuNPs are more suitable for biomedical applications [100].

\section{Conclusions and Perspectives}

In this article, we highlighted the biological method of synthesis of metallic NPs using algae. A special emphasis was given to AgNPs and AuNPs because of their unique features that have attracted much scientific and technologic interests. We described the main factors influencing a stable and efficient biosynthesis, as well as the most used algae for such purposes. We aimed to demonstrate the production of different sized NPs with many desirable shapes using various species of algae. We also provide some applications of metallic NPs in the field of nanomedicine, and their underlying main molecular mechanism-induced cytotoxicity. It is worth noting that algal-mediated NPs synthesis is a fast, cost-effective, and efficient strategy that has opened a way for nanotechnologists to produce desirable nanomaterials with clean energy processes. Nevertheless, there is a need to explore more in this field before these eco-friendly NPs are safely translated in medicine.

Funding: This research received no external funding.

Acknowledgments: F.M. would like to thank Cherif O. Aidara (McGill University, Montreal, Quebec, Canada) and Joel Cosson (University of Caen, Basse-Normandie, France), for our stimulating past discussions about potential innovative phycological applications and developments including in genetic engineering for optimized nanobioprocesses.

Conflicts of Interest: The authors declare no conflict of interests.

$\begin{array}{ll}\text { Abbreviations } & \\ \text { Silver } & \mathrm{Ag} \\ \text { Atomic force microscopy } & \mathrm{AFM} \\ \text { Gold } & \mathrm{Au} \\ \text { Cadmium sulfide } & \mathrm{CdS} \\ \text { Chitosan } & \mathrm{Cs} \\ \text { Copper (II) oxide } & \mathrm{CuO} \\ \text { Tumor microenvironment } & \mathrm{TME} \\ \text { Dynamic light scattering } & \mathrm{DLS} \\ \text { Iron (II) chloride } & \mathrm{FeCl} \\ \text { Iron (III) chloride } & \mathrm{FeCl}_{3} \\ \text { Fourier-transform infrared } & \mathrm{FTIR}^{\text {Chloroauric acid }} \\ \end{array}$




$\begin{array}{ll}\text { Magnetic resonance imaging } & \text { MRI } \\ \text { Nanoparticles } & \mathrm{NPs} \\ \text { Palladium } & \mathrm{Pd} \\ \text { Polyunsaturated fatty acids } & \mathrm{PUFAs} \\ \text { Reactive Oxygen Species } & \mathrm{ROS} \\ \text { Scanning electron microscopy } & \mathrm{SEM} \\ \text { Surface plasmon resonance } & \mathrm{SPR} \\ \text { Titanium dioxide } & \mathrm{TiO}_{2} \\ \text { Transmission electron microscopy } & \mathrm{TEM} \\ \text { Ultrasound irradiation-assisted synthesis } & \mathrm{UIAS} \\ \text { Ultraviolet-Visible } & \mathrm{UV}-\mathrm{Vis} \\ \text { X-ray powder diffraction } & \mathrm{XRD} \\ \text { Zinc oxide } & \mathrm{ZnO}\end{array}$

\section{References}

1. Batool, A.; Menaa, F.; Ali, K.B.; Uzair, B.; Menaa, B. Progress and prospects in translating nanobiotechnology in medical theranostics. Curr. Nanosci. 2019, 15, 1-23. [CrossRef]

2. Sharma, A.; Sharma, S.; Sharma, K.; Chetri, S.P.; Vashishtha, A.; Singh, P.; Kumar, R.; Rathi, B.; Agrawal, V. Algae as crucial organisms in advancing nanotechnology: A systematic review. J. Appl. Phycol. 2016, 28, 1759-1774. [CrossRef]

3. Menaa, F. When pharma meets nano or the emerging era of nanopharmaceuticals. Pharm. Anal. Acta 2013, 4, 223. [CrossRef]

4. Menaa, B. The importance of nanotechnology in biomedical sciences. J. Biotechnol. Biomater. 2011, 1, 105e. [CrossRef]

5. Tripathi, D.K.; Ahmad, P.; Sharma, S.; Chauhan, D.K.; Dubey, N.K. Nanomaterials in Plants, Algae, and Microorganisms: Concepts and Controversies; Academic Press: Cambridge, MA, USA, 2017; Volume 1.

6. Sharma, D.; Kanchi, S.; Bisetty, K. Biogenic synthesis of nanoparticles: A review. Arab. J. Chem. 2019, 12, 3576-3600. [CrossRef]

7. Borghans, L.; Duckworth, A.L.; Heckman, J.J.; Ter Weel, B. The economics and psychology of personality traits. J. Hum. Resour. 2008, 43, 972-1059.

8. Wang, H.-M.D.; Li, X.-C.; Lee, D.-J.; Chang, J.-S. Potential biomedical applications of marine algae. Bioresour. Technol. 2017, 244, 1407-1415. [CrossRef] [PubMed]

9. Khan, M.I.; Shin, J.H.; Kim, J.D. The promising future of microalgae: Current status, challenges, and optimization of a sustainable and renewable industry for biofuels, feed, and other products. Microb. Cell Factories 2018, 17, 36. [CrossRef]

10. LewisOscar, F.; Vismaya, S.; Arunkumar, M.; Thajuddin, N.; Dhanasekaran, D.; Nithya, C. Algal nanoparticles: Synthesis and biotechnological potentials. Chapter. Algae Org. Imminent Biotechnol. 2016, 7, 157-182. [CrossRef]

11. Hiraki, J. Basic and applied studies on E-polylysine. J. Antibact Antifung. Agents 1995, 23, 349-354.

12. Patel, J.K.; Sutariya, V.; Kanwar, J.R.; Pathak, Y.V. Drug Delivery for the Retina and Posterior Segment Disease, 1st ed.; Springer: Berlin/Heidelberg, Germany, 2018; p. 494. ISBN 978-3-319-95807-1.

13. Iqbal, H.; Khan, B.A.; Khan, Z.U.; Razzaq, A.; Khan, N.U.; Menaa, B.; Menaa, F. Fabrication, physical characterizations and in vitro antibacterial activity of cefadroxil-loaded chitosan/poly (vinyl alcohol) nanofibers against staphylococcus aureus clinical isolates. Int. J. Biol. Macromol. 2020, 144, 921-931. [CrossRef] [PubMed]

14. Chung, Y.-C.; Wang, H.-L.; Chen, Y.-M.; Li, S.-L. Effect of abiotic factors on the antibacterial activity of chitosan against waterborne pathogens. Bioresour. Technol. 2003, 88, 179-184. [CrossRef]

15. Muñoz-Bonilla, A.; Fernández-García, M. Polymeric materials with antimicrobial activity. Prog. Polym. Sci. 2012, 37, 281-339. [CrossRef]

16. Beyth, N.; Houri-Haddad, Y.; Domb, A.; Khan, W.; Hazan, R. Alternative antimicrobial approach: Nano-antimicrobial materials. Evid. Based Complementary Altern. Med. 2015, 2015, 246012. [CrossRef] [PubMed] 
17. Tiburu, E.K.; Salifu, A.; Aidoo, E.O.; Fleischer, H.N.; Manu, G.; Yaya, A.; Zhou, H.; Efavi, J.K. Formation of chitosan nanoparticles using deacetylated chitin isolated from freshwater algae and locally synthesized zeolite A and their influence on cancer cell growth. Proc. J. Nano Res. 2017, 48, 156-170. [CrossRef]

18. San, K.A.; Shon, Y.-S. Synthesis of alkanethiolate-capped metal nanoparticles using alkyl thiosulfate ligand precursors: A method to generate promising reagents for selective catalysis. Nanomaterials 2018, 8, 346. [CrossRef]

19. Garipov, I.T.; Khaydarov, R.R.; Gapurova, O.U.; Efimova, I.L.; Evgrafova, S.Y. Silver nanoparticles as a new generation of antimicrobial prophylaxis. J. Sib. Fed. Univ. Biol. 2019, 12, 266-276. [CrossRef]

20. Rai, M.; Yadav, A.; Gade, A. Silver nanoparticles as a new generation of antimicrobials. Biotechnol. Adv. 2009, 27, 76-83. [CrossRef]

21. Kumar, D.A.; Palanichamy, V.; Roopan, S.M. Photocatalytic action of AgCl nanoparticles and its antibacterial activity. J. Photochem. Photobiol. B Biol. 2014, 138, 302-306. [CrossRef]

22. Ninganagouda, S.; Rathod, V.; Singh, D.; Hiremath, J.; Singh, A.K.; Mathew, J. Growth kinetics and mechanistic action of reactive oxygen species released by silver nanoparticles from Aspergillus niger on Escherichia coli. Biomed Res. Int. 2014, 2014. [CrossRef]

23. Jin, T.; Sun, D.; Su, J.; Zhang, H.; Sue, H.J. Antimicrobial efficacy of zinc oxide quantum dots against Listeria monocytogenes, Salmonella enteritidis, and Escherichia coli O157: H7. J. Food Sci. 2009, 74, M46-M52. [CrossRef] [PubMed]

24. Blecher, K.; Nasir, A.; Friedman, A. The growing role of nanotechnology in combating infectious disease. Virulence 2011, 2, 395-401. [CrossRef] [PubMed]

25. Ruparelia, J.P.; Chatterjee, A.K.; Duttagupta, S.P.; Mukherji, S. Strain specificity in antimicrobial activity of silver and copper nanoparticles. Acta Biomater. 2008, 4, 707-716. [CrossRef] [PubMed]

26. Pelgrift, R.Y.; Friedman, A.J. Nanotechnology as a therapeutic tool to combat microbial resistance. Adv. Drug Deliv. Rev. 2013, 65, 1803-1815. [CrossRef] [PubMed]

27. Ghosh, P.; Han, G.; De, M.; Kim, C.K.; Rotello, V.M. Gold nanoparticles in delivery applications. Adv. Drug Deliv. Rev. 2008, 60, 1307-1315. [CrossRef] [PubMed]

28. Zeng, S.; Yong, K.-T.; Roy, I.; Dinh, X.-Q.; Yu, X.; Luan, F. A review on functionalized gold nanoparticles for biosensing applications. Plasmonics 2011, 6, 491. [CrossRef]

29. Huang, X.; Jain, P.K.; El-Sayed, I.H.; El-Sayed, M.A. Gold nanoparticles: Interesting optical properties and recent applications in cancer diagnostics and therapy. Nanomedicine 2007, 2, 681-693. [CrossRef]

30. Gupta, A.K.; Gupta, M. Synthesis and surface engineering of iron oxide nanoparticles for biomedical applications. Biomaterials 2005, 26, 3995-4021. [CrossRef]

31. Mahmoudi, M.; Sant, S.; Wang, B.; Laurent, S.; Sen, T. Superparamagnetic iron oxide nanoparticles (SPIONs): Development, surface modification and applications in chemotherapy. Adv. Drug Deliv. Rev. 2011, 63, 24-46. [CrossRef]

32. Thakkar, K.N.; Mhatre, S.S.; Parikh, R.Y. Biological synthesis of metallic nanoparticles. Nanomed. Nanotechnol. Biol. Med. 2010, 6, 257-262. [CrossRef]

33. Menaa, B.; Miyagawa, Y.; Takahashi, M.; Herrero, M.; Rives, V.; Menaa, F.; Eggers, D.K. Bioencapsulation of apomyoglobin in nanoporous organosilica sol-gel glasses: Influence of the siloxane network on the conformation and stability of a model protein. Biopolym. Orig. Res. Biomol. 2009, 91, 895-906. [CrossRef] [PubMed]

34. Sharma, G.; Pandey, S.; Ghatak, S.; Watal, G.; Rai, P.K. Potential of spectroscopic techniques in the characterization of "green nanomaterials". In Nanomaterials in Plants, Algae, and Microorganisms; Elsevier: Amsterdam, The Netherlands, 2018; pp. 59-77.

35. Shah, M.; Fawcett, D.; Sharma, S.; Tripathy, S.K.; Poinern, G.E.J. Green synthesis of metallic nanoparticles via biological entities. Materials 2015, 8, 7278-7308. [CrossRef] [PubMed]

36. Ghaemi, M.; Gholamipour, S. Controllable synthesis and characterization of silver nanoparticles using Sargassum angostifolium. Iran. J. Chem. Chem. Eng. (IJCCE) 2017, 36, 1-10.

37. Shou, Q.; Guo, C.; Yang, L.; Jia, L.; Liu, C.; Liu, H. Effect of pH on the single-step synthesis of gold nanoparticles using PEO-PPO-PEO triblock copolymers in aqueous media. J. Colloid Interface Sci. 2011, 363, 481-489. [CrossRef]

38. Devatha, C.P.; Thalla, A.K. Green synthesis of nanomaterials. In Synthesis of Inorganic Nanomaterials; Elsevier: Amsterdam, The Netherlands, 2018; pp. 169-184. 
39. Jiang, X.; Chen, W.; Chen, C.; Xiong, S.; Yu, A. Role of temperature in the growth of silver nanoparticles through a synergetic reduction approach. Nanoscale Res. Lett. 2011, 6, 32. [CrossRef] [PubMed]

40. Rai, A.; Singh, A.; Ahmad, A.; Sastry, M. Role of halide ions and temperature on the morphology of biologically synthesized gold nanotriangles. Langmuir 2006, 22, 736-741. [CrossRef]

41. Patra, J.K.; Baek, K.-H. Green nanobiotechnology: Factors affecting synthesis and characterization techniques. J. Nanomater. 2014, 2014, 417305. [CrossRef]

42. Chandran, S.P.; Chaudhary, M.; Pasricha, R.; Ahmad, A.; Sastry, M. Synthesis of gold nanotriangles and silver nanoparticles using Aloe vera plant extract. Biotechnol. Prog. 2006, 22, 577-583. [CrossRef]

43. Aboelfetoh, E.F.; El-Shenody, R.A.; Ghobara, M.M. Eco-friendly synthesis of silver nanoparticles using green algae (Caulerpa serrulata): Reaction optimization, catalytic and antibacterial activities. Environ. Monit. Assess. 2017, 189, 349. [CrossRef]

44. Ahmad, N.; Sharma, S. Green synthesis of silver nanoparticles using extracts of Ananas comosus. Green Sustain. Chem. 2012, 2, 141-147. [CrossRef]

45. Prathna, T.; Chandrasekaran, N.; Raichur, A.M.; Mukherjee, A. Kinetic evolution studies of silver nanoparticles in a bio-based green synthesis process. Colloids Surf. A Physicochem. Eng. Asp. 2011, 377, 212-216. [CrossRef]

46. Gutiérrez-Wing, C.; Velázquez-Salazar, J.J.; José-Yacamán, M. Procedures for the synthesis and capping of metal nanoparticles. In Nanoparticles in Biology and Medicine; Springer: Berlin/Heidelberg, Germany, 2012; pp. 3-19.

47. Rai, M.; Posten, C. Green Biosynthesis of Nanoparticles: Mechanisms and Applications; CABI: Wallingford, CT, USA, 2013; p. 248.

48. Khanna, P.; Kaur, A.; Goyal, D. Algae-based metallic nanoparticles: Synthesis, characterization and applications. J. Microbiol. Methods 2019, 163, 105656. [CrossRef]

49. Vincy, W.; Mahathalana, T.J.; Sukumaran, S.; Jeeva, S. Algae as a source for synthesis of nanoparticles-a review. Int. J. Latest Trends Eng. Technol. 2017, 5-9. [CrossRef]

50. Castro, L.; Blázquez, M.L.; Muñoz, J.A.; González, F.; Ballester, A. Biological synthesis of metallic nanoparticles using algae. IET Nanobiotechnol. 2013, 7, 109-116. [CrossRef]

51. Rajeshkumar, S.; Kannan, C.; Annadurai, G. Green synthesis of silver nanoparticles using marine brown algae Turbinaria conoides and its antibacterial activity. Int. J. Pharma Biol. Sci. 2012, 3, 502-510.

52. Dahoumane, S.A.; Mechouet, M.; Wijesekera, K.; Filipe, C.D.; Sicard, C.; Bazylinski, D.A.; Jeffryes, C. Algae-mediated biosynthesis of inorganic nanomaterials as a promising route in nanobiotechnology-a review. Green Chem. 2017, 19, 552-587. [CrossRef]

53. Brayner, R.; Barberousse, H.; Hemadi, M.; Djedjat, C.; Yéprémian, C.; Coradin, T.; Livage, J.; Fiévet, F.; Couté, A. Cyanobacteria as bioreactors for the synthesis of $\mathrm{Au}, \mathrm{Ag}, \mathrm{Pd}$, and $\mathrm{Pt}$ nanoparticles via an enzyme-mediated route. J. Nanosci. Nanotechnol. 2007, 7, 2696-2708. [CrossRef]

54. Kumar, B.; Smita, K.; Sánchez, E.; Guerra, S.; Cumbal, L. Nanotechnology ecofriendly ultrasound-assisted rapid synthesis of gold nanoparticles using Calothrix algae. Adv. Nat. Sci. Nanosci. Nanotechnol. 2016, 7, 025013. [CrossRef]

55. Kumar, B.; Cumbal, L.; Debut, A. Phycosynthesis of silver nanoparticles using Calothrix algae through ultrasonic method. In Proceedings of the XI Congreso de Ciencia Y Tecnologia ESPE, Sangolqui, Ecuador, 20-24 June 2016; pp. 213-216.

56. Jenaa, J.; Pradhan, N.; Dash, B.P.; Sukla, L.; Panda, P. Biosynthesis and characterization of silver nanoparticles using microalga Chlorococcum humicola and its antibacterial activity. Int. J. Nanomater. Biostructures 2013, 3, $1-8$.

57. Chokshi, K.; Pancha, I.; Ghosh, T.; Paliwal, C.; Maurya, R.; Ghosh, A.; Mishra, S. Green synthesis, characterization and antioxidant potential of silver nanoparticles biosynthesized from de-oiled biomass of thermotolerant oleaginous microalgae Acutodesmus dimorphus. RSC Adv. 2016, 6, 72269-72274. [CrossRef]

58. Garcia-Gonzalez, J.; Sommerfeld, M. Biofertilizer and biostimulant properties of the microalga Acutodesmus dimorphus. J. Appl. Phycol. 2016, 28, 1051-1061. [CrossRef] [PubMed]

59. Hashemi, S.; Givianrad, M.H.; Moradi, A.M.; Larijani, K. Biosynthesis of silver nanoparticles using brown marine seaweed Padina boeregeseni and evaluation of physico-chemical factors. Indian J. Geo Mar. Sci. 2015, $44,1415-1421$.

60. Senthilkumar, P.; Sudha, S.; Prakash, S. Antidiabetic activity of aqueous extract of padina boergesenii in streptozotocin-induced diabetic rats. Int. J. Pharm. Pharm. Sci. 2014, 6, 418-422. 
61. Senthilkumar, P.; Bhuvaneshwari, J.; Prakash, L.P.; Ranjith, S. Green synthesis and characterization of silver nanoparticles from aqueous extract brown seaweed of Padina boergesenii and its antifungal activity. World J. Pharm. Sci. 2015, 4, 1858-1870.

62. Ali, L.; Khan, A.L.; Al-Broumi, M.; Al-Harrasi, R.; Al-Kharusi, L.; Hussain, J.; Al-Harrasi, A. New enzyme-inhibitory triterpenoid from marine macro brown alga Padina boergesenii Allender \& Kraft. Mar. Drugs 2017, 15, 19. [CrossRef]

63. Rajamani, K.; Balasubramanian, T.; Thirugnanasambandan, S.S. Bioassay-guided isolation of triterpene from brown alga Padina boergesenii possess anti-inflammatory and anti-angiogenic potential with kinetic inhibition of $\beta$-carotene linoleate system. LWT 2018, 93, 549-555. [CrossRef]

64. Bhimba, B.V.; Devi, J.S.; Nandhini, S.U. Green synthesis and cytotoxicity of silver nanoparticles from extracts of the marine macroalgae Gracilaria corticata. Indian J. Biotechnol. 2015, 14, 276-281.

65. Naveena, B.E.; Prakash, S. Biological synthesis of gold nanoparticles using marine algae gracilaria corticata and its application as a potent antimicrobial and antioxidant agent. Asian J. Pharm. Clin. Res. 2013, 6, 179-182.

66. Kumar, P.; Selvi, S.S.; Govindaraju, M. Seaweed-mediated biosynthesis of silver nanoparticles using gracilaria corticata for its antifungal activity against Candida spp. Appl. Nanosci. 2013, 3, 495-500. [CrossRef]

67. Eahamban, K.; Marimuthu, J. Preliminary phytochemical, UV-VIS, HPLC and anti-bacterial studies on gracilaria corticata J. Ag. Asian Pac. J. Trop. Biomed. 2012, 2, S568-S574. [CrossRef]

68. Sudhakar, M.; Jagatheesan, A.; Perumal, K.; Arunkumar, K. Methods of phycobiliprotein extraction from Gracilaria crassa and its applications in food colourants. Algal Res. 2015, 8, 115-120.

69. Mahdieh, M.; Zolanvari, A.; Azimee, A.J.S.I. Green biosynthesis of silver nanoparticles by Spirulina platensis. Sci. Iran. 2012, 19, 926-929. [CrossRef]

70. Lupatini, A.L.; Colla, L.M.; Canan, C.; Colla, E. Potential application of microalga Spirulina platensis as a protein source. J. Sci. Food Agric. 2017, 97, 724-732. [CrossRef]

71. Belay, A.; Kato, T.; Ota, Y. Spirulina (Arthrospira): Potential application as an animal feed supplement. J. Appl. Phycol. 1996, 8, 303-311. [CrossRef]

72. Liu, Q.; Huang, Y.; Zhang, R.; Cai, T.; Cai, Y. Medical Application of Spirulina platensis Derived C-Phycocyanin. Evid. Based Complementary Altern. Med. Ecam. 2016, 2016, 7803846. [CrossRef]

73. Singh, G.; Babele, P.K.; Shahi, S.K.; Sinha, R.P.; Tyagi, M.B.; Kumar, A. Green synthesis of silver nanoparticles using cell extracts of Anabaena doliolum and screening of its antibacterial and antitumor activity. J. Microbiol. Biotechnol 2014, 24, 1354-1367. [CrossRef]

74. Singh, M.; Sharma, N.K.; Prasad, S.B.; Yadav, S.S.; Narayan, G.; Rai, A.K. The freshwater cyanobacterium Anabaena doliolum transformed with ApGSMT-DMT exhibited enhanced salt tolerance and protection to nitrogenase activity, but became halophilic. Microbiology 2013, 159, 641-648. [CrossRef] [PubMed]

75. El-Moslamy, S.; Kabeil, S.; Hafez, E.J.O. Bioprocess Development for Chlorella vulgaris cultivation and biosynthesis of anti-phytopathogens silver nanoparticles. J nanomater Mol nanotechnol 5: 1. J. Nanomater. Mol. Nanotechnol. 2016, 9, 2.

76. Arya, A.; Gupta, K.; Chundawat, T.S.; Vaya, D. Biogenic synthesis of copper and silver nanoparticles using green alga Botryococcus braunii and its antimicrobial activity. Bioinorg. Chem. Appl. 2018, 2018. [CrossRef]

77. Azizi, S.; Namvar, F.; Mahdavi, M.; Ahmad, M.B.; Mohamad, R.J.M. Biosynthesis of silver nanoparticles using brown marine macroalga, Sargassum muticum aqueous extract. Materials 2013, 6, 5942-5950. [CrossRef]

78. Prasad, T.N.; Kambala, V.S.R.; Naidu, R. Phyconanotechnology: Synthesis of silver nanoparticles using brown marine algae Cystophora moniliformis and their characterisation. J. Appl. Phycol. 2013, 25, 177-182. [CrossRef]

79. Rajesh, S.; Raja, D.P.; Rathi, J.; Sahayaraj, K. Biosynthesis of silver nanoparticles using Ulva fasciata (Delile) ethyl acetate extract and its activity against Xanthomonas campestris pv. malvacearum. J. Biopestic. 2012, 5, 119.

80. Sinha, S.N.; Paul, D.; Halder, N.; Sengupta, D.; Patra, S.K. Green synthesis of silver nanoparticles using fresh water green alga Pithophora oedogonia (Mont.) Wittrock and evaluation of their antibacterial activity. Appl. Nanosci. 2015, 5, 703-709. [CrossRef]

81. Shakibaie, M.; Forootanfar, H.; Mollazadeh-Moghaddam, K.; Bagherzadeh, Z.; Nafissi-Varcheh, N.; Shahverdi, A.R.; Faramarzi, M.A.J.B.; Biochemistry, A. Green synthesis of gold nanoparticles by the marine microalga Tetraselmis suecica. Biotechnol. Appl. Biochem. 2010, 57,71-75. [CrossRef] [PubMed] 
82. Dahoumane, S.A.; Djediat, C.; Yéprémian, C.; Couté, A.; Fiévet, F.; Coradin, T.; Brayner, R.J.B. Recycling and adaptation of Klebsormidium flaccidum microalgae for the sustained production of gold nanoparticles. Biotechnol. Bioeng. 2012, 109, 284-288. [CrossRef] [PubMed]

83. Singaravelu, G.; Arockiamary, J.; Kumar, V.G.; Govindaraju, K. A novel extracellular synthesis of monodisperse gold nanoparticles using marine alga, Sargassum wightii Greville. Colloids Surf. B Biointerfaces 2007, 57, 97-101. [CrossRef]

84. Singh, M.; Kalaivani, R.; Manikandan, S.; Sangeetha, N.; Kumaraguru, A. Facile green synthesis of variable metallic gold nanoparticle using Padina gymnospora, a brown marine macroalga. Appl. Nanosci. 2013, 3, 145-151. [CrossRef]

85. Venkatesan, J.; Manivasagan, P.; Kim, S.-K.; Kirthi, A.V.; Marimuthu, S.; Rahuman, A.A.J.B.; Engineering, B. Marine algae-mediated synthesis of gold nanoparticles using a novel Ecklonia cava. Bioprocess Biosyst. Eng. 2014, 37, 1591-1597. [CrossRef]

86. Kalabegishvili, T.; Kirkesali, E.I.; Rcheulishvili, A.N.; Ginturi, E.; Murusidze, I.; Kuchava, N.; Bagdavadze, N.; Tsertsvadze, G.; Gabunia, V.; Frontasyeva, M.; et al. Synthesis of gold nanoparticles by blue-green algae Spirulina platensis. Adv. Sci. Eng. Med. 2012, 4,1-7.

87. Lenartowicz, M.; Marek, P.H.; Madura, I.D.; Lipok, J. Formation of variously shaped gold nanoparticles by Anabaena laxa. J. Clust. Sci. 2017, 28, 3035-3055. [CrossRef]

88. Rajeshkumar, S.; Malarkodi, C.; Gnanajobitha, G.; Paulkumar, K.; Vanaja, M.; Kannan, C.; Annadurai, G. Seaweed-mediated synthesis of gold nanoparticles using Turbinaria conoides and its characterization. J. Nanostructure Chem. 2013, 3, 44. [CrossRef]

89. González-Ballesteros, N.; Prado-López, S.; Rodríguez-González, J.; Lastra, M.; Rodríguez-Argüelles, M.C. Green synthesis of gold nanoparticles using brown algae Cystoseira baccata: Its activity in colon cancer cells. Colloids Surf. Biointerfaces 2017, 153, 190-198. [CrossRef] [PubMed]

90. MubarakAli, D.; Gopinath, V.; Rameshbabu, N.; Thajuddin, N. Synthesis and characterization of CdS nanoparticles using C-phycoerythrin from the marine cyanobacteria. Mater. Lett. 2012, 74, 8-11. [CrossRef]

91. Mandal, R.P.; Sekh, S.; Sarkar, N.S.; Chattopadhyay, D.; De, S. Algae mediated synthesis of cadmium sulphide nanoparticles and their application in bioremediation. Mater. Res. Express 2016, 3, 055007. [CrossRef]

92. Abboud, Y.; Saffaj, T.; Chagraoui, A.; El Bouari, A.; Brouzi, K.; Tanane, O.; Ihssane, B. Biosynthesis, characterization and antimicrobial activity of copper oxide nanoparticles (CONPs) produced using brown alga extract (Bifurcaria bifurcata). Appl. Nanosci. 2014, 4, 571-576. [CrossRef]

93. Bhattacharya, P.; Swarnakar, S.; Ghosh, S.; Majumdar, S.; Banerjee, S. Disinfection of drinking water via algae mediated green synthesized copper oxide nanoparticles and its toxicity evaluation. J. Environ. Chem. Eng. 2019, 7, 102867. [CrossRef]

94. Mahdavi, M.; Namvar, F.; Ahmad, M.B.; Mohamad, R.J.M. Green biosynthesis and characterization of magnetic iron oxide ( $\mathrm{Fe} 3 \mathrm{O} 4$ ) nanoparticles using seaweed (Sargassum muticum) aqueous extract. Molecules 2013, 18, 5954-5964. [CrossRef]

95. El-Kassas, H.Y.; Aly-Eldeen, M.A.; Gharib, S.M. Green synthesis of iron oxide $\left(\mathrm{Fe}_{3} \mathrm{O}_{4}\right)$ nanoparticles using two selected brown seaweeds: Characterization and application for lead bioremediation. Acta Oceanol. Sin. 2016, 35, 89-98. [CrossRef]

96. Momeni, S.; Nabipour, I. A simple green synthesis of palladium nanoparticles with Sargassum alga and their electrocatalytic activities towards hydrogen peroxide. Appl. Biochem. Biotechnol. 2015, 176, 1937-1949. [CrossRef] [PubMed]

97. Sayadi, M.H.; Salmani, N.; Heidari, A.; Rezaei, M.R. Bio-synthesis of palladium nanoparticle using Spirulina platensis alga extract and its application as adsorbent. Surf. Interfaces 2018, 10, 136-143. [CrossRef]

98. Priyadharshini, R.I.; Prasannaraj, G.; Geetha, N.; Venkatachalam, P. Microwave-mediated extracellular synthesis of metallic silver and zinc oxide nanoparticles using macro-algae (Gracilaria edulis) extracts and its anticancer activity against human PC3 cell lines. Appl. Biochem. Biotechnol. 2014, 174, 2777-2790. [CrossRef]

99. Azizi, S.; Ahmad, M.B.; Namvar, F.; Mohamad, R. Green biosynthesis and characterization of zinc oxide nanoparticles using brown marine macroalga Sargassum muticum aqueous extract. Mater. Lett. 2014, 116, 275-277. [CrossRef]

100. Fard, J.K.; Jafari, S.; Eghbal, M.A. A review of molecular mechanisms involved in toxicity of nanoparticles. Adv. Pharm. Bull. 2015, 5, 447. [CrossRef] [PubMed] 
101. Lim, S.; Park, J.; Shim, M.K.; Um, W.; Yoon, H.Y.; Ryu, J.H.; Lim, D.-K.; Kim, K. Recent advances and challenges of repurposing nanoparticle-based drug delivery systems to enhance cancer immunotherapy. Theranostics 2019, 9, 7906. [CrossRef] [PubMed]

102. Khalid, M.; Khalid, N.; Ahmed, I.; Hanif, R.; Ismail, M.; Janjua, H.A. Comparative studies of three novel freshwater microalgae strains for synthesis of silver nanoparticles: Insights of characterization, antibacterial, cytotoxicity and antiviral activities. J. Appl. Phycol. 2017, 29, 1851-1863. [CrossRef]

103. Venkatesan, J.; Kim, S.-K.; Shim, M.S. Antimicrobial, antioxidant, and anticancer activities of biosynthesized silver nanoparticles using marine algae Ecklonia cava. Nanomaterials 2016, 6, 235. [CrossRef] [PubMed]

104. Khan, A.; Rashid, R.; Murtaza, G.; Zahra, A. Gold nanoparticles: Synthesis and applications in drug delivery. Trop. J. Pharm. Res. 2014, 13, 1169-1177. [CrossRef]

105. Chugh, H.; Sood, D.; Chandra, I.; Tomar, V.; Dhawan, G.; Chandra, R. Role of gold and silver nanoparticles in cancer nano-medicine. Artif. Cells Nanomed. Biotechnol. 2018, 46, 1210-1220. [CrossRef]

106. Murugesan, S.; Bhuvaneswari, S.; Shanthi, N.; Murugakoothan, P.; Sivamurugan, V. Red alga Hypnea musciformis (Wulf) lamour mediated environmentally benign synthesis and antifungal activity of gold nano particles. Int. J. Nanosci. Nanotech. 2015, 6, 71-83.

107. Arvizo, R.; Bhattacharya, R.; Mukherjee, P. Gold nanoparticles: Opportunities and challenges in nanomedicine. Expert Opin. Drug Deliv. 2010, 7, 753-763. [CrossRef]

108. Coradeghini, R.; Gioria, S.; García, C.P.; Nativo, P.; Franchini, F.; Gilliland, D.; Ponti, J.; Rossi, F. Size-dependent toxicity and cell interaction mechanisms of gold nanoparticles on mouse fibroblasts. Toxicol. Lett. 2013, 217, 205-216. [CrossRef]

109. Kohout, C.; Santi, C.; Polito, L. Anisotropic gold nanoparticles in biomedical applications. Int. J. Mol. Sci. 2018, 19, 3385. [CrossRef] [PubMed]

Publisher's Note: MDPI stays neutral with regard to jurisdictional claims in published maps and institutional affiliations. 